\title{
Hepatitis C Virus Infection in Persons Who Inject Drugs in the Middle East and North Africa: Intervention Strategies
}

\author{
Jag H. Khalsa ${ }^{1,2, *}$ and Poonam Mathur ${ }^{2}$ \\ 1 Medical Consequences of Drug Abuse and Infections Branch, Division of Therapeutics and Medical \\ Consequences, National Institute on Drug Abuse, National Institutes of Health, Bethesda, MD 20892, USA \\ 2 Institute of Human Virology, University of Maryland School of Medicine, Baltimore, MD 21201, USA; \\ pmathur@ihv.umaryland.edu \\ * Correspondence: jkhalsa@yahoo.com
}

Citation: Khalsa, J.H.; Mathur, P.

Hepatitis C Virus Infection in Persons Who Inject Drugs in the Middle East and North Africa: Intervention Strategies. Viruses 2021, 13, 1363. https://doi.org/10.3390/v13071363

Academic Editor:

François-Loïc Cosset

Received: 10 June 2021

Accepted: 11 July 2021

Published: 14 July 2021

Publisher's Note: MDPI stays neutral with regard to jurisdictional claims in published maps and institutional affiliations.

Copyright: (c) 2021 by the authors. Licensee MDPI, Basel, Switzerland. This article is an open access article distributed under the terms and conditions of the Creative Commons Attribution (CC BY) license (https:// creativecommons.org/licenses/by/ $4.0 /)$.

\begin{abstract}
There is a high incidence and prevalence of hepatitis $C$ viral infection in persons with or without substance use disorders (SUDs) in the Middle East and North Africa (MENA) region, but only a small number receive comprehensive care. Highly effective direct-acting antiviral (DAA) medications are available at substantially lower costs; however, complete elimination of the hepatitis $\mathrm{C}$ virus $(\mathrm{HCV})$ can only be achieved if integrated care strategies target those at highest risk for HCV infection and transmission and improve access to care. Due to the high prevalence of SUD in the MENA region, strategies to eliminate $\mathrm{HCV}$ must focus on integrated healthcare across multiple subspecialties, including addiction medicine, psychiatry, infectious diseases, hepatology, and social work. In this invited manuscript, we review the epidemiology of HCV in the MENA region and highlight intervention strategies to attain the WHO's goal of HCV eradication by 2030.
\end{abstract}

Keywords: hepatitis C virus infection; substance use disorder; intervention strategies; Middle East; North Africa (MENA)

\section{Introduction}

Hepatitis $\mathrm{C}$ virus (HCV) is a blood-borne pathogen caused by a hepatotrophic, singlestranded ribonucleic acid (RNA) virus. The acute phase of HCV infection may last about six months and cause no symptoms; an estimated $15-25 \%$ of these people spontaneously clear the infection and recover. However, the remaining $75-85 \%$ develop chronic HCV infection. Even in chronic $\mathrm{HCV}$, people may be asymptomatic for $25-30$ years; however, $20 \%$ of these individuals eventually develop liver cirrhosis, hepatic decompensation, and/or hepatocellular carcinoma (HCC), which are associated with high morbidity and mortality [1-3]. In 2017, the World Health Organization (WHO) reported that an estimated 71 million people were infected with HCV globally [3], and, in 2016, approximately 399,000 people died from HCV, mostly due to cirrhosis and hepatocellular carcinoma. A major hurdle in determining global epidemiology is the discrepancy between various serology assays and the lack of confirmation of chronicity due to the requirement of expensive HCV RNA testing. However, recent validation studies conducted by the POLARIS Observatory determined a $1 \%$ seroprevalence of $\mathrm{HCV}$ prevalence globally [4]. They also defined HCV prevalence in populations at risk: the pooled mean rate ranged between $57.4 \%$ (95\% CI: 49.4-65.2\%) in people who inject drugs and $75.5 \%$ (95\% CI: $61.0-87.6 \%)$ in populations with liver-related conditions [5].

Symptoms of untreated HCV are often extrahepatic, manifesting most commonly as arthralgia, paresthesia, myalgia, pruritus, sicca syndrome, and sensory neuropathy. However, untreated HCV can lead to progressive liver damage and fibrosis, causing advanced or decompensated liver disease. Chronic liver disease causes synthetic liver dysfunction and portal hypertension, which results in mental status changes (hepatic encephalopathy), volume overload, and varices. HCV is a leading cause of HCC in western 
countries and increases the risk of cancer 15-20-fold [6]. Successful eradication of HCV reduces the risk of HCC by $71-75 \%$ [7].

The treatment of HCV has evolved over the last 10 years, with the advent of oral directacting antivirals (DAAs) [8]. Prior to 2011, the mainstay of HCV treatment was pegylated interferon and ribavirin. These two medications had limited efficacy and numerous side effects; a systematic review and meta-analysis estimated that only $25 \%$ of patients with chronic HCV infection were treated with these therapies [9]. The cure rate associated with DAAs is approximately $98 \%$ [10], which is much higher than the $50 \%$ cure rate associated with interferon-based therapy [11]. Now that the potency of HCV treatment has improved, the focus has shifted to expanding access to treatment and decreasing HCV-associated morbidity and mortality. In 2016, the World Health Organization (WHO) adopted the Global Health Sector Strategy on Viral Hepatitis, 2016-2021. The strategy envisions eliminating hepatitis (B and C) as a global public health problem and commits to a WHO-led effort to eliminate hepatitis B and C by 2030 [3].

The WHO recognizes that mortality from $\mathrm{HBV}$ and $\mathrm{HCV}$ mainly persists due to poor access to treatment. Therefore, it is pertinent to focus on how to target marginalized populations who are at high risk for $\mathrm{HCV}$ acquisition and transmission. In particular, campaigns have focused on targeting people who inject drugs (PWIDs). Different regions of the world have identified that increasing HCV treatment access for PWIDs is crucial to achieving the WHO's goal of HCV elimination in the next 9 years. In the United States, $80 \%$ of HCV transmission occurs among PWIDs [12]. In Europe, HCV prevalence in PWIDs is between $39.9 \%$ and $28.6 \%$, whereas HCV prevalence in the general population is $1.5 \%$ [13]. In India, the HCV prevalence rate is $44.7 \%$ among PWIDs, almost double that of any other high-risk group, whereas the generalized community prevalence is $0.85 \%$ [14]. Among other Southeast Asian countries, it is recognized that injection drug use remains an important route of $\mathrm{HCV}$ transmission, with HCV infecting more PWIDs than HIV or hepatitis B [15].

Difficulties arise in identifying where the care cascade is failing in low- and middleincome countries (LMICs). Though data on these countries exist, systematic analyses and subsequent policies to guide strategic intervention are limited by large, nationallevel studies [14,15]. It is estimated that over $80 \%$ of the world's HCV infections are in LMICs [16]. The Middle East and North Africa region, for example, is an area that numerous review papers [5,17-23] have alluded to as a hub for the global burden of HCV due to the number of LMICs in the region and the rising prevalence of injection drug use. For example, in Egypt, Morocco, and the United Arab Emirates, viremic rates in HCV-positive individuals in the general population were approximately $70 \%$; the viremic prevalence varied from $0.7 \%$ (2011) in Saudi Arabia to 5.8\% (2007-2008) in Pakistan and 10.0\% (2008) in Egypt [17]. However, epidemiologic data from this region is lacking, and there is no consensus regarding intervention strategies that would be beneficial to eradicate $\mathrm{HCV}$ in this area. In this review, we briefly discuss what is known regarding HCV epidemiology in the MENA region, then focus on strategies that can be implemented to eliminate HCV in the area.

\section{HCV Epidemiology in the MENA Region}

The prevalence of viral hepatitis is generally higher in Middle Eastern countries than in Europe and the USA, possibly due to the migration of infected Asian persons [24]. Of the 560 million people in 20 countries in the MENA region ( $8 \%$ of the world's population), the overall pooled mean viremic rate is $67.6 \%$ (95\% CI: $64.9-70.3 \%)$, but the prevalence of $\mathrm{HCV}$ infection in each country varies. The prevalence was very low $(<1 \%)$ in Iran, Cyprus, Saudi Arabia, Sudan, and Lebanon [25,26]; low $(<1.5 \%)$ in Djibouti, Kuwait, Oman, Qatar, and the UAE; moderate (1.5-3.5\%) in Algeria, Iraq, Lebanon, Libya, Morocco, Saudi Arabia, Sudan, Syria, and Tunisia; and high (>3.5\%) in Egypt, Pakistan, and Yemen. In Pakistan, the HCV prevalence decreased from $6.7 \%$ in 2007-2008 [17] to $4.2 \%$ (7,001,000 cases) [27] in 2015. The highest prevalence of HCV infection, not just in MENA, but in the world, is in 
Egypt. The prevalence was $17.5 \%$ [28] in 2013, but decreased to $10 \%$ in 2015 [29] due to increased screening initiatives and governmental treatment programs.

There is tremendous genotype diversity in the MENA region. Chronic HCV infections are highest among genotype 3, followed by genotypes 4, 1, and 2 [20]. Genotype 1 is dominant ( $\geq 50 \%$ of HCV infections) in Algeria, Iran, Morocco, Oman, Tunisia, and the UAE, but is distributed ubiquitously across the MENA region. Genotype 2 is common (10-50\%) in Northern Africa (Algeria, Libya, and Morocco) and Bahrain. Genotype 3 is the most common in Afghanistan and Pakistan, and genotype 4 is predominant in Egypt, Iraq, Jordan, Palestine, Qatar, Saudi Arabia, and Syria. Genotypes 5, 6, and 7 are essentially absent.

\section{Risk Factors for HCV Transmission}

Before screening for $\mathrm{HCV}$ became available, $\mathrm{HCV}$ infection was transmitted mainly by transfusion of contaminated blood or blood products. The other modes of exposure are healthcare-related exposures $(59.5 \%)$, community-related exposures $(15.8 \%)$, sexualrelated exposures $(3.7 \%)$, surgical and other medical procedures, dental work, and medical injections [20,30]. In the MENA region, the major risk factors for HCV transmission have been blood transfusions and hemodialysis due to the prevalence of beta-thalassemia major and end-stage renal disease. In addition, healthcare also appears to be the driver of prevalent (and possibly incident) infections in MENA, followed by injection drug use [20].

However, the global trend of transmission has shifted such that contaminated needles, syringes, and other instruments for injections and skin-piercing procedures harbor enormous risk. Among high-risk populations, PWIDs carry the highest prevalence of $\mathrm{HCV}$ seropositivity [31]. Transmission of HCV among PWIDs is greatest with "direct sharing" of needles and syringes but may also occur indirectly via sharing of injection paraphernalia, such as syringes, cookers, and cotton filters [32-34]. Approximately $20 \%$ to $30 \%$ of PWIDs become infected with $\mathrm{HCV}$ within the first 2 years of injecting drugs and $50 \%$ within 5 years [35].

Regarding health care access, even though persons with substance use disorders have the highest $\mathrm{HCV}$ prevalence and incidence, the vast majority have not engaged in care for the infection. Previously, interferon-based treatments, with substantial side effects and the propensity to exacerbate mental health conditions, were the major disincentives to pursue care for the infection. Data show that only $2 \%$ to $20 \%$ of PWIDs with HCV infection are linked to care [36]. Direct-acting antivirals, with viral eradication rates of $>90 \%$, significantly improved side effect profiles and shortened treatment duration; these dramatic advances over prior treatment regimens should promote widespread hepatitis $C$ virus care among persons with substance use disorders [36]. Research shows that HCV treatment has been delivered successfully to PWID through various multidisciplinary models such as community-based clinics, substance abuse treatment clinics, and specialized hospital-based clinics. Models may be integrated into primary care-all under one roof in either addiction care units or general practitioner-based models-or can occur in secondary or tertiary care settings. Additional innovative models include directly observed therapy, peer-based models, and maintenance on opioid substitution therapy (OST) with methadone or buprenorphine [37-39]. It is important to note that OST is associated with sustained virologic response (SVR) rates of $94 \%$ to $97 \%$, regardless of ongoing drug use [40,41]. However, PWIDs successfully treated with DAAs must be followed and tested frequently for reinfection. A recent study of collocation of $\mathrm{HCV}$ care in harm reduction centers allowed active PWID to engage in HCV treatment, OST and needle syringe programs, and preexposure prophylaxis (PrEP) for HIV. SVR rates were high in this population, and high-risk behaviors for $\mathrm{HCV}$ reinfection were reduced [42].

\section{Injection Drug Use and Substance Use Disorders in the MENA Region}

Due to the stigma associated with substance use, PWIDs in the MENA region are difficult to access for epidemiologic and treatment purposes [16]. The prevalence of injection drug use (IDU) in the MENA region is rising [16,43], estimated to be 0.24 per 100 adults 
(626,000 persons) [44]. IDU seems to be mostly among men, but women who inject drugs are difficult to reach, so epidemiologic data may be skewed. However, injection drug use among women may be related to sex work or having a sexual partner who is a PWID [44]. Though data are limited, the prevalence of HCV in PWIDs is increasing. In 2006 , although the overall weighted prevalence of HCV in Iran was $0.5 \%$, the rate was significantly higher in men $(1.0 \%)$ than in women $(0.1 \%)$. In multivariate analysis, male sex, history of intravenous drug abuse, and imprisonment were significantly associated with HCV [45]. In areas such as Lebanon and Syria, the HCV prevalence ranged from 40-61\% among PWIDs [44]. A pooled analysis suggests that half of PWIDs in the MENA region have been infected with HCV [46]. Substance use disorders from alcohol and marijuana are prevalent in the Middle East, but in the MENA region, heroin is the most reported injectable drug [16]. Substance use has been a neglected area of public health, though it has been recognized as an important risk for SUD-related harms, including HIV- and HCV-associated morbidity [16]. HCV infection exacerbates the morbidity and mortality associated with these agents, as the hepatotoxic effects of these agents can rapidly progress to liver fibrosis. Since highly marginalized individuals such as people who inject drugs are the predominantly affected populations, innovative strategies are therefore required to enhance screening and linkage to care for so-called "hard-to-reach" populations. Several reviews and models have demonstrated that targeting PWIDs for HCV treatment is imperative to eradicating HCV globally [47-51]. Thus, it is of paramount importance that appropriate collocated strategies are developed and employed in the MENA region, to clinically manage PWIDs and HCV infection.

\section{Intervention Strategies for the MENA Region}

Hepatitis C elimination campaigns in lower-middle-income countries have been successful by targeting several key intervention points along the HCV care continuum. However, the substantial out-of-pocket costs for the treatment present an important barrier to service access. For example, patient assistance programs, combined with generic brands of newer hepatitis $C$ treatment, offer a significant cost reduction and widen access to hepatitis $C$ treatment in low- and middle-income countries [52-54]. Egypt was particularly successful with a national hepatitis C strategy [55] that provided no-cost DAA-based HCV treatment to more than 2 million people between 2014 and 2017. In 2018, Egypt introduced a national screening initiative that screened an impressive 49.6 million people in 7 months (79.4\% of the target population). Using Egypt's initiative as an exemplary model, we propose several interventions that must be implemented in the entire MENA region and outline those below.

Nationwide Mandate for Testing: The strategy of seek, test, treat, and retain (STTR) was found to be effective in expanding the HIV care continuum [56,57]. In the United States, the Centers for Disease Control recommends that persons born between 1945 and 1965 in the U.S. are screened for HCV infection [58], based on the period when blood transfusions were widely used but not screened for infectious diseases. The MENA region should develop its recommendations based on the risk factors for HCV transmission.

Nationwide Availability for Point-of-care Testing: In the MENA region and worldwide, many remain unsure of their $\mathrm{HCV}$ infection status because current testing requires at least a two-step process: (1) determination of HCV serostatus, followed by (2) HCV RNA or core antigen testing to confirm active infection. Implementing point-of-care testing using $\mathrm{HCV}$ core antigen would reduce loss-to-follow-up and increase the engagement of PWIDs into $\mathrm{HCV}$ care [59-62]. Efficient testing can also be employed using novel methods/technologies, such as the mobile health vans program (A-CHESS), which allows for the implementation of several services and the collection of longitudinal data related to drug use and HCV care among people with opioid use disorders [63], and telehealth, which is cost-effective, saves time, and facilitates outreach/access to HCV treatment [64].

Public Awareness and Treatment Availability: Mobilize public awareness campaigns to destigmatize HCV screening and treatment. Surveys of hepatitis programs in LMICs 
have shown that one of the major challenges to scaling up hepatitis care is limited community awareness of hepatitis [65,66]. Worldwide, only $41 \%$ of LMICs have a funded public awareness campaign for hepatitis $C$, and less than half have spent funds raising awareness [67]. To increase public knowledge in LMICs, lessons on the importance of awareness campaigns can be taken from HIV and applied to HCV, since the risk factors for each are similar. For example, in the 1990s, people with HIV in Thailand launched a campaign for universal access to healthcare with one slogan: "Why are medications so expensive?" Within 10 years, nearly half of those who needed treatment received it under a national healthcare program, and Thailand became a widely praised success story in the global response to AIDS [68]. The impact of efficient, creative public awareness campaigns in MENA cannot be underestimated, and they are vital to eliminating the stigma of HCV in the population, especially among PWIDs.

Treatment Availability: Publicize the low-cost of DAA treatments and appeal for government-mandated subsidization [69]. The largest barrier to accessing DAAs in LMICs is the exorbitant cost. The cost of sofosbuvir is substantially lower in the Middle Eastern countries such as Egypt (EGP 900 for 12 weeks of therapy) compared to costs of USD 84,000, GBP 54,000, and EUR 25,000 in the U.S., U.K., and Spain, respectively [70]. Sofosbuvir-based regimens effectively treat all HCV genotypes, including genotype 4, which is the most common among PWIDs in the MENA region [19]. Therefore, successful HCV eradication can be achieved in the MENA region with subsidized costs of sofosbuvir-based regimens. There are little data available on the cost-effectiveness of expanded versus restrictive treatment in LMICs and PWIDs in the MENA region. However, available studies suggest that there are substantial health benefits when HCV treatment is broadly delivered, and very low drug prices are necessary for cost-effectiveness [71]. In addition, treatment of individuals who are likely to transmit the virus (PWIDs) may have a considerable impact on reducing disease incidence and prevalence, based on data from other regions [71,72].

Integration/Collocation of HCV Treatment with OST and Harm-reduction: Engagement of PWIDs in HCV care has been difficult due to stigmatization of the HCV diagnosis in the MENA region. This causes discomfort during conventional health care settings and interactions with providers, and a public lack of HCV awareness. Other factors contribute to difficulty in engaging PWIDs, including multiple comorbidities (HIV, hepatitis B virus (HBV) infection, and polysubstance addiction), physician reluctance to treat PWIDs, required sobriety for treatment, lack of engagement in OST before HCV treatment, and limited access to DAAs due to the lack of a coordinated government effort [73]. In addition to promoting engagement in care, treatment can be collocated with OST and syringe exchange programs for harm reduction, and minimization of risk for HCV re-infection and HIV infection (via PrEP). Collocated treatment centers should be modeled like the National Rehabilitation Center (NRC) in Abu Dhabi, geographically and strategically located in the MENA region where patients with SUD, mental illness, or high-risk behaviors can be effectively treated with medications to treat SUD and/or HCV while receiving robust psychosocial and peer support. These centers could prove vital to the elimination of HCV infection in the MENA region. Modeling shows that harm-reduction strategies are necessary for HCV elimination, as they would provide sustainability post-SVR and reduce the rate of re-infection [74]. Currently, many MENA countries have no explicit plans for harm reduction strategies in their national HCV elimination policies [16].

Epidemiologic Research: Increase epidemiologic research on risk factors for $\mathrm{HCV}$ transmission. Research is needed to further characterize the status of HCV epidemiology in the MENA region. To date, there has been little to no investigation into populations besides PWIDs who are at high risk for HCV infection, including men who have sex with men (MSMs) and sex workers. By understanding the epidemiology of HCV transmission in this region, further public health campaigns can be developed to remove the stigma associated with testing in these populations. Epidemiologic surveys would be an effective modality for determining the risk factors, incidence, and prevalence of HCV infection in these high-risk populations. 
Regulatory Policies: Lobby for government-mandated safety policies for blood banks. In some parts of the MENA region, a major risk factor for HCV transmission is still blood transfusions. Therefore, it is pertinent to implement and enforce strong regulatory policies for all blood banks and hospitals, while holding them accountable for the safety of health care workers.

Multi-disciplinary Clinical Care: Employ physicians with expertise in addiction medicine, infectious diseases, gastroenterology, hepatology, other clinical specialties, nurses, social workers, and others to provide integrated clinical care as recently shown by the ASCEND [75] and ANCHOR [42] studies. In addition, task-shifting mechanisms can be employed to establish training programs for new physicians and health care providers to clinically manage these populations [52,76].

Treatment for Incarcerated PWIDs with HCV Infection: Establish treatment programs for incarcerated persons with HCV infection, and ensure they are linked to care once they enter the general population [77]. Pegylated-interferon and ribavirin regimens have been used to successfully treat $\mathrm{HCV}$-infected persons in prison [78], so the use of less complicated, more effective DAA regimens may also be successful. In Australia, scale-up of DAA treatment in prisons reduced transmission, supporting a treatment-as-prevention approach in incarcerated individuals [79]. In addition, mathematical models show that treating HCV-infected prisoners with DAAs is cost-effective [80].

\section{Conclusions}

The incidence and prevalence of hepatitis $C$ viral infection are significantly high in PWIDs in the MENA region, but only a small number receive comprehensive care aimed at HCV therapy and harm reduction. Cost-effective DAA therapies are available in the MENA region. Therefore, complete elimination of the virus can be achieved in this region if strategies target PWIDs infected with HCV. In addition, epidemiologic data on persons with other SUDs and high-risk behavior must be collected, and these populations linked to comprehensive care that includes screening for infectious diseases. Increasing screening and access to treatment will have significant economic and health care impacts in the region by reducing morbidity and mortality. Utilizing collocated care models in the MENA region will allow providers to engage and link marginalized patients, including PWIDs, to enhance comprehensive care that will improve long-term outcomes. To meet the goal of complete elimination of HCV infection in the MENA region by 2030, it is of paramount importance that the healthcare community and policymakers implement effective strategies to significantly enhance the $\mathrm{HCV}$ care continuum in the area.

Author Contributions: Conceptualization J.H.K.; Writing—original draft J.H.K.; Writing—review \& editing P.M. All authors have read and agreed to the published version of the manuscript.

Funding: P.M.: This work is supported by the National Institutes of Health/National Heart, Lung, Blood Institute Grant 5K12HL143886-02; J.H.K.: Self.

Institutional Review Board Statement: Not applicable.

Informed Consent Statement: Not applicable.

Data Availability Statement: The information regarding data on each cited study can be obtained from the individual author cited.

Acknowledgments: We are grateful to Shyam Kottilil, Director of Clinical Care and Research, Institute of Human Virology, University of Maryland School of Medicine, for his highly valuable suggestions throughout the preparation of this review. In addition, Khalsa appreciates the opportunity to serve as a Special Volunteer at the U.S. National Institute on Drug Abuse, National Institutes of Health, Department of Health and Human Services, from where he retired in 2017 after serving for 30 years as the Chief for the Medical Consequences of Drug Abuse and Infections Branch.

Conflicts of Interest: The observations are those of the authors and do not necessarily reflect the views of their respective organizations (NIDA, NIH, DHHS; IHV). 


\section{References}

1. Maasoumy, B.; Wedemeyer, H. Natural history of acute and chronic hepatitis C. Best Pract. Res. Clin. Gastroenterol. 2012, 26, 401-412. [CrossRef]

2. Sandmann, L.; Schulte, B.; Manns, M.P.; Maasoumy, B. Treatment of Chronic Hepatitis C: Efficacy, Side Effects and Complications. Visc. Med. 2019, 35, 161-170. [CrossRef]

3. World Health Organization. Global Hepatitis Report; World Health Organization: Geneva, Switzerland, 2017; ISBN 978-924-156545-5. Available online: https://www.who.int/publications/i/item/global-hepatitis-report-2017 (accessed on 10 June 2021).

4. The Polaris Observatory HCV Collaborators. Global prevalence and genotype distribution of hepatitis C virus infection in 2015: A modelling study. Lancet Gastroenterol. Hepatol. 2017, 2, 161-176. [CrossRef]

5. Harfouche, M.; Chemaitelly, H.; Kouyoumjian, S.P.; Mahmud, S.; Chaabna, K.; Al-Kanaani, Z.; Abu-Raddad, L.J. Hepatitis C virus viremic rate in the Middle East and North Africa: Systematic synthesis, meta-analyses, and meta-regressions. PLoS ONE 2017, 12, e0187177. [CrossRef]

6. Axley, P.; Ahmed, Z.; Ravi, S.; Singal, A.K. Hepatitis C Virus and Hepatocellular Carcinoma: A Narrative Review. J. Clin. Transl. Hepatol. 2018, 6, 79-84. [CrossRef]

7. Dandachi, D.; Hassan, M.; Kaseb, A.; Angelidakis, G.; Torres, H.A. Hepatitis C virus-associated hepatocellular carcinoma as a second primary malignancy: Exposing an overlooked presentation of liver cancer. J. Hepatocell. Carcinoma 2018, 5, 81-86. [CrossRef] [PubMed]

8. Kohli, A.; Shaffer, A.; Sherman, A.; Kottilil, S. Treatment of hepatitis C: A systematic review. JAMA 2014, 312, 631-640. [CrossRef] [PubMed]

9. Vutien, P.; Jin, M.; Le, M.H.; Nguyen, P.; Trinh, S.; Huang, J.F.; Yu, M.L.; Chuang, W.L.; Nguyen, M.H. Regional differences in treatment rates for patients with chronic hepatitis C infection: Systematic review and meta-analysis. PLoS ONE 2017, 12, e0183851. [CrossRef]

10. Inglis, S.K.; Beer, L.J.; Byrne, C.; Malaguti, A.; Robinson, E.; Sharkey, C.; Gillings, K.; Stephens, B.; Dillon, J.F. Randomised controlled trial conducted in injecting equipment provision sites to compare the effectiveness of different hepatitis $\mathrm{C}$ treatment regimens in people who inject drugs: A Direct obserVed therApy versus fortNightly CollEction study for HCV treatmentADVANCE HCV protocol study. BMJ Open 2019, 9, e029516. [CrossRef] [PubMed]

11. Kalidindi, Y.; Jung, J.; Feldman, R.; Riley, T., 3rd. Association of Direct-Acting Antiviral Treatment with Mortality among Medicare Beneficiaries with Hepatitis C. JAMA Netw. Open 2020, 3, e2011055. [CrossRef] [PubMed]

12. Zibbell, J.E.; Asher, A.K.; Patel, R.C.; Kupronis, B.; Iqbal, K.; Ward, J.W.; Holtzman, D. Increases in Acute Hepatitis C Virus Infection Related to a Growing Opioid Epidemic and Associated Injection Drug Use, United States, 2004 to 2014. Am. J. Public Health 2018, 108, 175-181. [CrossRef]

13. Torrens, M.; Soyemi, T.; Bowman, D.; Schatz, E. Beyond clinical outcomes: The social and healthcare system implications of hepatitis C treatment. BMC Infect. Dis. 2020, 20, 702. [CrossRef]

14. Goel, A.; Seguy, N.; Aggarwal, R. Burden of hepatitis C virus infection in India: A systematic review and meta-analysis. J. Gastroenterol. Hepatol. 2019, 34, 321-329. [CrossRef]

15. Wait, S.; Kell, E.; Hamid, S.; Muljono, D.H.; Sollano, J.; Mohamed, R.; Shah, S.; Al Mamun, M.; Abbas, Z.; Johnston, J.; et al. Hepatitis B and hepatitis C in southeast and southern Asia: Challenges for governments. Lancet Gastroenterol. Hepatol. 2016, 1, 248-255. [CrossRef]

16. Aaraj, E.; Jreij Abou Chrouch, M. Drug policy and harm reduction in the Middle East and North Africa: The role of civil society. Int. J. Drug Policy 2016, 31, 168-171. [CrossRef]

17. Chaabna, K.; Cheema, S.; Abraham, A.; Alrouh, H.; Lowenfels, A.B.; Maisonneuve, P.; Mamtani, R. Systematic overview of hepatitis C infection in the Middle East and North Africa. World J. Gastroenterol. 2018, 24, 3038-3054. [CrossRef]

18. Chemaitelly, H.; Mahmud, S.; Kouyoumjian, S.P.; Al-Kanaani, Z.; Hermez, J.G.; Abu-Raddad, L.J. Who to Test for Hepatitis C Virus in the Middle East and North Africa?: Pooled Analyses of 2500 Prevalence Measures, Including 49 Million Tests. Hepatol. Commun. 2019, 3, 325-339. [CrossRef]

19. Mahmud, S.; Al-Kanaani, Z.; Chemaitelly, H.; Chaabna, K.; Kouyoumjian, S.P.; Abu-Raddad, L.J. Hepatitis C virus genotypes in the Middle East and North Africa: Distribution, diversity, and patterns. J. Med. Virol. 2018, 90, 131-141. [CrossRef]

20. Mahmud, S.; Kouyoumjian, S.P.; Al Kanaani, Z.; Chemaitelly, H.; Abu-Raddad, L.J. Individual-level key associations and modes of exposure for hepatitis C virus infection in the Middle East and North Africa: A systematic synthesis. Ann. Epidemiol. 2018, 28, 452-461. [CrossRef]

21. Mohamoud, Y.A.; Mumtaz, G.R.; Riome, S.; Miller, D.; Abu-Raddad, L.J. The epidemiology of hepatitis C virus in Egypt: A systematic review and data synthesis. BMC Infect. Dis. 2013, 13, 288. [CrossRef]

22. Mohamoud, Y.A.; Riome, S.; Abu-Raddad, L.J. Epidemiology of hepatitis C virus in the Arabian Gulf countries: Systematic review and meta-analysis of prevalence. Int. J. Infect. Dis. 2016, 46, 116-125. [CrossRef]

23. Sibley, A.; Han, K.H.; Abourached, A.; Lesmana, L.A.; Makara, M.; Jafri, W.; Salupere, R.; Assiri, A.M.; Goldis, A.; Abaalkhail, F.; et al. The present and future disease burden of hepatitis $C$ virus infections with today's treatment paradigm-Volume 3. J. Viral Hepat. 2015, 22 (Suppl. 4), 21-41. [CrossRef] 
24. Coppola, N.; Alessio, L.; Onorato, L.; Sagnelli, C.; Macera, M.; Sagnelli, E.; Pisaturo, M. Epidemiology and management of hepatitis C virus infections in immigrant populations. Infect. Dis. Poverty 2019, 8, 17. [CrossRef] [PubMed]

25. Askarian, M.; Mansour Ghanaie, R.; Karimi, A.; Habibzadeh, F. Infectious diseases in Iran: A bird's eye view. Clin. Microbiol. Infect. 2012, 18, 1081-1088. [CrossRef] [PubMed]

26. Ramia, S.; Melhem, N.M.; Kreidieh, K. Hepatitis C virus infection in the Middle East and North Africa "MENA" region: Injecting drug users (IDUs) is an under-investigated population. Infection 2012, 40,1-10. [CrossRef] [PubMed]

27. Liakina, V.; Hamid, S.; Tanaka, J.; Olafsson, S.; Sharara, A.I.; Alavian, S.M.; Gheorghe, L.; El Hassan, E.S.; Abaalkhail, F.; Abbas, Z.; et al. Historical epidemiology of hepatitis C virus (HCV) in select countries-Volume 3. J. Viral Hepat. 2015, 22 (Suppl. 4), 4-20. [CrossRef]

28. Karoney, M.J.; Siika, A.M. Hepatitis C virus (HCV) infection in Africa: A review. Pan Afr. Med. J. 2013, 14, 44. [CrossRef] [PubMed]

29. Omran, D.; Alboraie, M.; Zayed, R.A.; Wifi, M.N.; Naguib, M.; Eltabbakh, M.; Abdellah, M.; Sherief, A.F.; Maklad, S.; Eldemellawy, H.H.; et al. Towards hepatitis $\mathrm{C}$ virus elimination: Egyptian experience, achievements and limitations. World J. Gastroenterol. 2018, 24, 4330-4340. [CrossRef]

30. Al Kanaani, Z.; Mahmud, S.; Kouyoumjian, S.P.; Abu-Raddad, L.J. The epidemiology of hepatitis C virus in Pakistan: Systematic review and meta-analyses. R. Soc. Open Sci. 2018, 5, 180257. [CrossRef]

31. Midgard, H.; Weir, A.; Palmateer, N.; Lo Re, V., 3rd; Pineda, J.A.; Macias, J.; Dalgard, O. HCV epidemiology in high-risk groups and the risk of reinfection. J. Hepatol. 2016, 65, S33-S45. [CrossRef]

32. Hagan, H.; Pouget, E.R.; Des Jarlais, D.C. A systematic review and meta-analysis of interventions to prevent hepatitis C virus infection in people who inject drugs. J. Infect. Dis. 2011, 204, 74-83. [CrossRef] [PubMed]

33. Holtzman, D.; Barry, V.; Ouellet, L.J.; Des Jarlais, D.C.; Vlahov, D.; Golub, E.T.; Hudson, S.M.; Garfein, R.S. The influence of needle exchange programs on injection risk behaviors and infection with hepatitis $C$ virus among young injection drug users in select cities in the United States, 1994-2004. Prev. Med. 2009, 49, 68-73. [CrossRef] [PubMed]

34. Pouget, E.R.; Hagan, H.; Des Jarlais, D.C. Meta-analysis of hepatitis C seroconversion in relation to shared syringes and drug preparation equipment. Addiction 2012, 107, 1057-1065. [CrossRef]

35. Hagan, H.; Pouget, E.R.; Des Jarlais, D.C.; Lelutiu-Weinberger, C. Meta-regression of hepatitis C virus infection in relation to time since onset of illicit drug injection: The influence of time and place. Am. J. Epidemiol. 2008, 168, 1099-1109. [CrossRef] [PubMed]

36. Gonzalez, S.A.; Fierer, D.S.; Talal, A.H. Medical and behavioral approaches to engage people who inject drugs into care for hepatitis c virus infection. Addict. Disord. Their Treat. 2017, 16, S1-S23. [CrossRef]

37. Bruggmann, P.; Litwin, A.H. Models of care for the management of hepatitis C virus among people who inject drugs: One size does not fit all. Clin. Infect. Dis. 2013, 57 (Suppl. 2), S56-S61. [CrossRef]

38. Dimova, R.B.; Zeremski, M.; Jacobson, I.M.; Hagan, H.; Des Jarlais, D.C.; Talal, A.H. Determinants of hepatitis C virus treatment completion and efficacy in drug users assessed by meta-analysis. Clin. Infect. Dis. 2013, 56, 806-816. [CrossRef]

39. Martinez, A.D.; Dimova, R.; Marks, K.M.; Beeder, A.B.; Zeremski, M.; Kreek, M.J.; Talal, A.H. Integrated internist-Addiction medicine-Hepatology model for hepatitis C management for individuals on methadone maintenance. J. Viral Hepat. 2012, 19, 47-54. [CrossRef]

40. Dore, G.J.; Altice, F.; Litwin, A.H.; Dalgard, O.; Gane, E.J.; Shibolet, O.; Luetkemeyer, A.; Nahass, R.; Peng, C.Y.; Conway, B.; et al. Elbasvir-Grazoprevir to Treat Hepatitis C Virus Infection in Persons Receiving Opioid Agonist Therapy: A Randomized Trial. Ann. Intern. Med. 2016, 165, 625-634. [CrossRef]

41. Grebely, J.; Dore, G.J.; Zeuzem, S.; Aspinall, R.J.; Fox, R.; Han, L.; McNally, J.; Osinusi, A.; Brainard, D.M.; Subramanian, G.M.; et al. Efficacy and Safety of Sofosbuvir/Velpatasvir in Patients with Chronic Hepatitis C Virus Infection Receiving Opioid Substitution Therapy: Analysis of Phase 3 ASTRAL Trials. Clin. Infect. Dis. 2016, 63, 1479-1481. [CrossRef] [PubMed]

42. Rosenthal, E.S.; Silk, R.; Mathur, P.; Gross, C.; Eyasu, R.; Nussdorf, L.; Hill, K.; Brokus, C.; D'Amore, A.; Sidique, N.; et al. Concurrent Initiation of Hepatitis C and Opioid Use Disorder Treatment in People Who Inject Drugs. Clin. Infect. Dis. 2020, 71, 1715-1722. [CrossRef]

43. Beyrer, C.; Wirtz, A.L.; Baral, S.; Peryskina, A.; Sifakis, F. Epidemiologic links between drug use and HIV epidemics: An international perspective. J. Acquir. Immune Defic. Syndr. 2010, 55 (Suppl. 1), S10-S16. [CrossRef]

44. Mumtaz, G.R.; Weiss, H.A.; Thomas, S.L.; Riome, S.; Setayesh, H.; Riedner, G.; Semini, I.; Tawil, O.; Akala, F.A.; Wilson, D.; et al. HIV among people who inject drugs in the Middle East and North Africa: Systematic review and data synthesis. PLoS Med. 2014, 11, e1001663. [CrossRef]

45. Merat, S.; Rezvan, H.; Nouraie, M.; Jafari, E.; Abolghasemi, H.; Radmard, A.R.; Zaer-rezaii, H.; Amini-Kafiabad, S.; Maghsudlu, M.; Pourshams, A.; et al. Seroprevalence of hepatitis C virus: The first population-based study from Iran. Int. J. Infect. Dis. 2010, 14 (Suppl. 3), e113-e116. [CrossRef] [PubMed]

46. Mahmud, S.; Mumtaz, G.R.; Chemaitelly, H.; Al Kanaani, Z.; Kouyoumjian, S.P.; Hermez, J.G.; Abu-Raddad, L.J. The status of hepatitis C virus infection among people who inject drugs in the Middle East and North Africa. Addiction 2020, 115, 1244-1262. [CrossRef] [PubMed]

47. Day, E.; Hellard, M.; Treloar, C.; Bruneau, J.; Martin, N.K.; Ovrehus, A.; Dalgard, O.; Lloyd, A.; Dillon, J.; Hickman, M.; et al. Hepatitis $C$ elimination among people who inject drugs: Challenges and recommendations for action within a health systems framework. Liver Int. 2019, 39, 20-30. [CrossRef] 
48. Heffernan, A.; Cooke, G.S.; Nayagam, S.; Thursz, M.; Hallett, T.B. Scaling up prevention and treatment towards the elimination of hepatitis C: A global mathematical model. Lancet 2019, 393, 1319-1329. [CrossRef]

49. Trickey, A.; Fraser, H.; Lim, A.G.; Peacock, A.; Colledge, S.; Walker, J.G.; Leung, J.; Grebely, J.; Larney, S.; Martin, N.K.; et al. The contribution of injection drug use to hepatitis $\mathrm{C}$ virus transmission globally, regionally, and at country level: A modelling study. Lancet Gastroenterol. Hepatol. 2019, 4, 435-444. [CrossRef]

50. Dore, G.J.; Bajis, S. Hepatitis C virus elimination: Laying the foundation for achieving 2030 targets. Nat. Rev. Gastroenterol. Hepatol. 2021, 18, 91-92. [CrossRef]

51. Martinez, I.; Ryan, P.; Valencia, J.; Resino, S. The Challenging Road to Hepatitis C Virus Eradication. J. Clin. Med. 2021, 10, 611. [CrossRef] [PubMed]

52. Mathur, P.; Comstock, E.; Makuza, J.D.; Emmanuel, B.; Sebeza, J.; Kiromera, A.; Wilson, E.; Kattakuzhy, S.; Nelson, A.; Kottilil, S.; et al. Implementation of a unique hepatitis C care continuum model in Rwanda. J. Public Health 2019, 41, e203-e208. [CrossRef]

53. Ali, S.; Ur-Rehman, T.; Ali, M.; Haque, S.; Rasheed, F.; Lougher, E.; Nawaz, M.S.; Paudyal, V. Improving access to the treatment of hepatitis $\mathrm{C}$ in low- and middle-income countries: Evaluation of a patient assistance programme. Int. J. Clin. Pharm. 2020. [CrossRef]

54. Zhang, M.; O’Keefe, D.; Craig, J.; Samley, K.; Bunreth, V.; Jolivet, P.; Balkan, S.; Marquardt, T.; Dousset, J.P.; Le Paih, M. Decentralised hepatitis $C$ testing and treatment in rural Cambodia: Evaluation of a simplified service model integrated in an existing public health system. Lancet Gastroenterol. Hepatol. 2021, 6, 371-380. [CrossRef]

55. Waked, I.; Esmat, G.; Elsharkawy, A.; El-Serafy, M.; Abdel-Razek, W.; Ghalab, R.; Elshishiney, G.; Salah, A.; Abdel Megid, S.; Kabil, K.; et al. Screening and Treatment Program to Eliminate Hepatitis C in Egypt. N. Engl. J. Med. 2020, 382, 1166-1174. [CrossRef] [PubMed]

56. Beckwith, C.G.; Kuo, I.; Fredericksen, R.J.; Brinkley-Rubinstein, L.; Cunningham, W.E.; Springer, S.A.; Loeliger, K.B.; Franks, J.; Christopoulos, K.; Lorvick, J.; et al. Risk behaviors and HIV care continuum outcomes among criminal justice-involved HIV-infected transgender women and cisgender men: Data from the Seek, Test, Treat, and Retain Harmonization Initiative. PLoS ONE 2018, 13, e0197730. [CrossRef] [PubMed]

57. Doshi, R.K.; Malebranche, D.; Bowleg, L.; Sangaramoorthy, T. Health care and HIV testing experiences among Black men in the South: Implications for "Seek, Test, Treat, and Retain" HIV prevention strategies. AIDS Patient Care STDS 2013, 27, 123-133. [CrossRef]

58. Smith, B.D.; Morgan, R.L.; Beckett, G.A.; Falck-Ytter, Y.; Holtzman, D.; Teo, C.G.; Jewett, A.; Baack, B.; Rein, D.B.; Patel, N.; et al. Recommendations for the identification of chronic hepatitis $C$ virus infection among persons born during 1945-1965. MMWR Recomm. Rep. 2012, 61, 1-32. [PubMed]

59. Freiman, J.M.; Tran, T.M.; Schumacher, S.G.; White, L.F.; Ongarello, S.; Cohn, J.; Easterbrook, P.J.; Linas, B.P.; Denkinger, C.M. Hepatitis C Core Antigen Testing for Diagnosis of Hepatitis C Virus Infection: A Systematic Review and Meta-analysis. Ann. Intern. Med. 2016, 165, 345-355. [CrossRef]

60. Mathur, P.; Kottilil, S. Hepatitis C Core Antigen Testing: Still an Effective Diagnostic Method for Global Elimination of Hepatitis C. Clin. Infect. Dis. 2020, 70, 674-675. [CrossRef]

61. Blackburn, N.A.; Patel, R.C.; Zibbell, J.E. Improving Screening Methods for Hepatitis C among People Who Inject Drugs: Findings from the HepTLC Initiative, 2012-2014. Public Health Rep. 2016, 131 (Suppl. 2), 91-97. [CrossRef]

62. Jewett, A.; Smith, B.D.; Garfein, R.S.; Cuevas-Mota, J.; Teshale, E.H.; Weinbaum, C.M. Field-based performance of three pre-market rapid hepatitis $C$ virus antibody assays in STAHR (Study to Assess Hepatitis C Risk) among young adults who inject drugs in San Diego, CA. J. Clin. Virol 2012, 54, 213-217. [CrossRef]

63. Hochstatter, K.R.; Gustafson, D.H., Sr.; Landucci, G.; Pe-Romashko, K.; Maus, A.; Shah, D.V.; Taylor, Q.A.; Gill, E.K.; Miller, R.; Krechel, S.; et al. A Mobile Health Intervention to Improve Hepatitis C Outcomes among People with Opioid Use Disorder: Protocol for a Randomized Controlled Trial. JMIR Res. Protoc. 2019, 8, e12620. [CrossRef]

64. Schulz, T.R.; Kanhutu, K.; Sasadeusz, J.; Watkinson, S.; Biggs, B.A. Using telehealth to improve access to hepatitis C treatment in the direct-acting antiviral therapy era. J. Telemed. Telecare 2020, 26, 180-185. [CrossRef]

65. Ishizaki, A.; Bouscaillou, J.; Luhmann, N.; Liu, S.; Chua, R.; Walsh, N.; Hess, S.; Ivanova, E.; Roberts, T.; Easterbrook, P. Survey of programmatic experiences and challenges in delivery of hepatitis B and C testing in low- and middle-income countries. BMC Infect. Dis. 2017, 17, 696. [CrossRef]

66. Reipold, E.I.; Trianni, A.; Krakower, D.; Ongarello, S.; Roberts, T.; Easterbrook, P.; Denkinger, C. Values, preferences and current hepatitis B and C testing practices in low- and middle-income countries: Results of a survey of end users and implementers. BMC Infect. Dis. 2017, 17, 702. [CrossRef]

67. Van Damme, P.; Lavanchy, D.; Hendrickx, G.; Lodewyckx, I.; Vorsters, A. Innovative Financing into Hepatitis B and C Prevention and Treatment in Low and Middle Income Countries; IFPMA: Geneva, Switzerland, 2016.

68. Kaplan, K. Activist Strategies for Increasing Access to HCV Treatment in Low- and Middle-Income Countries; Swan, T., Chou, L., Benzacar, A., Eds.; Treatment Action Group: New York, NY, USA, 2015.

69. Suthar, A.B.; Harries, A.D. A public health approach to hepatitis C control in low- and middle-income countries. PLoS Med. 2015, 12, e1001795. [CrossRef]

70. Rosenthal, E.S.; Graham, C.S. Price and affordability of direct-acting antiviral regimens for hepatitis C virus in the United States. Infect. Agents Cancer 2016, 11, 24. [CrossRef] 
71. Cipriano, L.E.; Goldhaber-Fiebert, J.D. Population Health and Cost-Effectiveness Implications of a "Treat All" Recommendation for HCV: A Review of the Model-Based Evidence. MDM Policy Pract. 2018, 3, 2381468318776634. [CrossRef] [PubMed]

72. Martin, N.K.; Vickerman, P.; Dore, G.J.; Grebely, J.; Miners, A.; Cairns, J.; Foster, G.R.; Hutchinson, S.J.; Goldberg, D.J.; Martin, T.C.S.; et al. Prioritization of HCV treatment in the direct-acting antiviral era: An economic evaluation. J. Hepatol. 2016, 65, 17-25. [CrossRef] [PubMed]

73. Talal, A.H.; Thomas, D.L.; Reynolds, J.L.; Khalsa, J.H. Toward Optimal Control of Hepatitis C Virus Infection in Persons with Substance Use Disorders. Ann. Intern. Med. 2017, 166, 897-898. [CrossRef] [PubMed]

74. Gountas, I.; Sypsa, V.; Blach, S.; Razavi, H.; Hatzakis, A. HCV elimination among people who inject drugs. Modelling pre- and post-WHO elimination era. PLOS ONE 2018, 13, e202109. [CrossRef] [PubMed]

75. Kattakuzhy, S.; Gross, C.; Emmanuel, B.; Teferi, G.; Jenkins, V.; Silk, R.; Akoth, E.; Thomas, A.; Ahmed, C.; Espinosa, M.; et al. Expansion of Treatment for Hepatitis C Virus Infection by Task Shifting to Community-Based Nonspecialist Providers: A Nonrandomized Clinical Trial. Ann. Intern. Med. 2017, 167, 311-318. [CrossRef] [PubMed]

76. Page, K.; Qeadan, F.; Qualls, C.; Thornton, K.; Arora, S. Project ECHO Revisited: Propensity Score Analysis and HCV Treatment Outcomes. Hepat. Med. 2019, 11, 149-152. [CrossRef] [PubMed]

77. Martin, N.K.; Vickerman, P.; Dore, G.J.; Hickman, M. The hepatitis C virus epidemics in key populations (including people who inject drugs, prisoners and MSM): The use of direct-acting antivirals as treatment for prevention. Curr. Opin. HIV AIDS 2015, 10, 374-380. [CrossRef]

78. Maru, D.S.; Bruce, R.D.; Basu, S.; Altice, F.L. Clinical outcomes of hepatitis C treatment in a prison setting: Feasibility and effectiveness for challenging treatment populations. Clin. Infect. Dis. 2008, 47, 952-961. [CrossRef]

79. Hajarizadeh, B.; Grebely, J.; Byrne, M.; Marks, P.; Amin, J.; McManus, H.; Butler, T.; Cunningham, E.B.; Vickerman, P.; Martin, N.K.; et al. Evaluation of hepatitis C treatment-as-prevention within Australian prisons (SToP-C): A prospective cohort study. Lancet Gastroenterol. Hepatol. 2021. [CrossRef]

80. Kwon, J.A.; Chambers, G.M.; Luciani, F.; Zhang, L.; Kinathil, S.; Kim, D.; Thein, H.H.; Botha, W.; Thompson, S.; Lloyd, A.; et al. Hepatitis C treatment strategies in prisons: A cost-effectiveness analysis. PLoS ONE 2021, 16, e0245896. [CrossRef] 